\title{
Evaluation of the Ameliorative Roles of Vitamins A, C and E on Aspartate Amino Transferase in Clarias gariepinus (Burchell, 1822) Fingerlings Exposed to Camium Chloride
} \author{
Mohammad Hadiza Lami ${ }^{2}$ \\ ${ }^{1}$ Department of Animal Biology, Federal University of Technology, Minna, Nigeria \\ ${ }^{2}$ Department of Biochemistry, Federal University of Technology, Minna, Nigeria
}

Samuel Patrick Ozovehe ${ }^{1}$, Arimoro Francis Ofurum ${ }^{1}$, Ayanwale Adesola Victoria ${ }^{1}$,

Email address:

ajakopatrick@yahoo.com (S. P. Ozovehe)

\section{To cite this article:}

Samuel Patrick Ozovehe, Arimoro Francis Ofurum, Ayanwale Adesola Victoria, Mohammad Hadiza Lami. Evaluation of the Ameliorative Roles of Vitamins A, C and E on Aspartate Amino Transferase in Clarias gariepinus (Burchell, 1822) Fingerlings Exposed to Camium Chloride. International Journal of Ecotoxicology and Ecobiology. Vol. 6, No. 1, 2021, pp. 19-28. doi: 10.11648/j.ijee.20210601.15

Received: February 8, 2021; Accepted: February 23, 2021; Published: March 30, 2021

\begin{abstract}
The anthropogenic activities culminating in environmental pollution usually lead to release of plethora of pollutants such as cadmium calls for concern. The effects of $\mathrm{CdCl}_{2}$ on the production of aspartate amino transferase (AST) in C. gariepinus and how they can be ameliorated through administration of vitamins were investigated. C. gariepinus fingerlings (whose initial weight ranged from 3-11g) were exposed to sub-lethal concentrations of Cd $(00,12 \mathrm{mg} / \mathrm{L}, 16 \mathrm{mg} / \mathrm{L}, 20 \mathrm{mg} / \mathrm{L}$ and $24 \mathrm{mg} / \mathrm{L}$ ) with replicate in each case. In each case, $12 \mathrm{mg} / \mathrm{L}$ of the vitamin was administered across all buds. Fresh concentrations of both toxicant and vitamins were administered every 72 hours for a period of 12 weeks every time the water medium was changed. The various treatments group include Cd only, CdVA, CdVC and CdVE. 3 samples of the fish were randomly selected and sacrificed from each aquarium tank every 2 weeks of the exposure period. The gills, kidneys and liver were excised from these specimens and homogenized in sodium phosphate buffer. From the results: in Cd only, the highest AST produced in the liver was $135.00 \pm 0.18 \mathrm{nM} / \mathrm{mg}$ in $\mathrm{T}_{1}$. The highest AST produced in the kidneys of the fish was $145.00 \pm 0.18 \mathrm{nM} / \mathrm{mg}$ in $\mathrm{T}_{3}$. The highest AST produced in the gill was $137.97 \pm 0.09 \mathrm{nM} / \mathrm{mg}$ in $\mathrm{T}_{1}$. In CDVA samples, the highest AST produced in the liver was $132.19 \pm 0.18 \mathrm{nM} / \mathrm{mg}$ in $\mathrm{T}_{4}$. The highest AST produced in the kidneys was $113.91 \pm 0.09 \mathrm{nM} / \mathrm{mg}$ in $\mathrm{T}_{1}$. In the gills, the highest AST value was $120.94 \pm 0.36 \mathrm{nM} / \mathrm{mg}$ in $\mathrm{T}_{1}$. In the samples exposed to CdVC, the highest AST produced in the liver was $128.44 \pm 0.36 \mathrm{nM} / \mathrm{mg}$ in $\mathrm{T}_{1}$. The highest mean value of AST produced in the kidneys was $114.84 \pm 0.09 \mathrm{nM} / \mathrm{mg}$ in $\mathrm{T}_{3}$. In the gills of the samples, the highest AST value was $125.16 \pm 0.27 \mathrm{nM} / \mathrm{mg}$ in $\mathrm{T}_{2}$. In CdVE samples, the highest AST produced in the liver was $150.63 \pm 0.18 \mathrm{nM} / \mathrm{mg}$ in $\mathrm{T}_{2}$. The kidneys' highest AST value of $125.78 \pm 0.27 \mathrm{nM} / \mathrm{mg}$ was recorded in $\mathrm{T}_{4}$. In the gills of the samples, the highest AST produced in the gills of the fish was $133.28 \pm 0.09 \mathrm{nM} / \mathrm{mg}$ in $\mathrm{T}_{1}$. There were general high production levels of AST in all treatments with the highest values recorded in the liver of CdVA, CdVC and CdVE groups mostly in samples exposed to lower concentrations. The kidneys in the Cd only group however, produced the highest AST value. The high production values of AST in all treatments suggest that the enzyme is a good biomarker of oxidative stress elicited by the presence of the toxicant.
\end{abstract}

Keywords: Clarias gariepinus, Aspartate Amino Transferase, Ameliorative Roles, Vitamin Supplements, Cd Treatment Groups

\section{Introduction}

Fish is a rich source of animal protein throughout the world. It also serves both subsistent and commercial purposes in many developing countries of the world. African catfish,
Clarias gariepinus is an important commercial fish due to its high growth rate, high consumer acceptability, and ability to withstand poor water quality, and oxygen depletion $[2,18]$.

The African cat fish, Clarias gariepinus is a tropical hardy species belonging to the Phylum Chordata, class 
Actinopterygii and family Clariidae. Clarias species is a widely distributed fish in Asia and Africa. In these areas, the fish is extremely popular on account of its tasty flesh, its unparalleled hardness, its rapid growth and its somewhat acceptable market price [15]. In Nigeria, Clarias species is an indigenous fish occurring in freshwater throughout the country. It is suspected that apart from tilapia, Clarias is the most abundant cultivated fish species in Nigeria [15]. The common species found are Clarias gariepinus, Clarias anguillaris, Clarias buthupogon and Clarias lazera.

The presence of pollutants in the environment of an aquatic organism such as fish can lead to the production of reactive oxygen species and consequently, oxidative stress. Heavy metals are known to elicit oxidative stress in organisms when the threshold is exceeded. Heavy metals are also known to promote oxidative damage by increasing the cellular concentration of reactive oxygen species (ROS) in fish, consequently, a response of antioxidative defences [21]. Heavy metals could be essential or non-essential. Heavy metals such as $\mathrm{Fe}, \mathrm{Cu}, \mathrm{Zn}, \mathrm{Ni}, \mathrm{Co}, \mathrm{Cr}$, and $\mathrm{Mn}$ are vital to human only at lower concentrations, but they become more toxic when they are taken up more than the biorecommended limits [27]. It is also known that even essential metals may be toxic on the biological activities of organisms above certain concentrations [20]. Fish are particularly vulnerable and heavily exposed to pollutants due to feeding and living in aquatic ecosystems, because they cannot avoid pollutant harmful effects [4]. Heavy metals enter fish by direct absorption from water through their gills and skin, or by ingestion of contaminated food [8]. Heavy metals induce significant damage to the physiologic and biochemical processes of the fish and subsequently to fish consumers [19].

Among all the heavy metals, $\mathrm{Cd}$, arsenic, mercury and lead pose highest degree of toxicity and that is of great concern to plants and human health [7]. Antioxidant enzymes are crucial in their effort to decrease oxidative stress produced by exposure to toxicants [25]. It has also been reported that antioxidant may ameliorate, protect and remove the oxidative damage to a target organ or molecule [13].

Vitamins A, C and E are known to play ameliorative roles in the attenuation of the effects of pollutants on organisms. Fishes survive oxidative stress by mobilizing enzymatic as well as non-enzymatic antioxidant defences [3, 29]. Also, Vitamins $\mathrm{C}$ and $\mathrm{E}$ supplementations have been reported to play a positive role in detoxification of mercury toxicity especially at lower concentrations [28]. Vitamin C is known to play a crucial role in the immunological and antioxidant properties of vertebrates capable of maintaining the integrity, fluidity of membranes and capable of controlling the oxidizing reactions of fatty acids, thus keeping cellular respiration and avoiding cell death [1]. Non-enzymatic antioxidants such as vitamins $\mathrm{C}$ and $\mathrm{E}$ can also act to overcome oxidative stress, being a part of the total antioxidant system. They prevent the increased production of free radicals induced by oxidative damage to lipids and lipoproteins in various cellular compartments and tissues. The main biological function of vitamin $\mathrm{E}$ is its direct influence on cellular responses to oxidative stress through modulation of signal transduction pathway [23]. Vitamins E and $\mathrm{C}$ supplementation can induce protective effects on certain conditions after free radical-mediated cellular damage or disruption [31]. Vitamin E ( $\alpha$-tocopherol) is a fat soluble antioxidant that inhibits the production of reactive oxygen species formed when fat undergoes oxidation.

Aspartate aminotransferase (AST) and alanine aminotransferase (ALT) belong to the plasma non-functional enzymes which are normally localized within the cells of liver, heart, gills, kidneys, muscle and other organs. These enzymes are liberated into the blood in pathological situations and therefore are of clinical importance. AST and ALT are highly conservative indicators in liver, and are commonly located in hepatic cytoplasm and would release into the circulation when hepatocytes necrotize [6]. The presence of pollutant can trigger the utilization or increased production of AST. For instance, cadmium in plasma of goldfish significantly increased the activities of plasma glutamic acid oxaloacetic acid-transaminase (GOT) and glutamic acid-pyruvic acid transaminase (GPT) [32].

Ellakany and Gaafar [11] reported that in Oreochromis niloticus, there was a marked reduction in AST in liver and muscle in response to the lower or higher level of ochratoxin. They attributed the reduced levels of aminotransfersase in various organs to tissue damage and consequently the reduction of enzyme biosynthesis for reasons related to the presence of ochratoxin. On the other hand, the ALT activities in liver and muscle were found to increase during the time course of endogenous cortisol elevation induced by ochratoxin intoxication. The results obtained also indicated that the tissue injury in toxicated fish recovered when they were fed dietary ascorbic acid because the AST and ALT activities in fish exposed to the lower or higher dose of ochratoxin + vitamin C became similar to those of control fish. The ameliorative role of vitamins was evident when Vitamin $\mathrm{E}$ and metallothionein treatments protected against $\mathrm{Cd}$-induced damage of liver in grass carp by decreasing AST and ALT content, repairing organelles, and maintained the antioxidant system by elevating CAT, SOD, and GSH-Px activity and regulating related mRNA transcript expression [16]. This research therefore, addresses the effects of Cd toxicant on AST production levels and how such effects can be attenuated to certain extent by administration of vitamin supplements.

\section{Materials and Methods}

\subsection{Samples/Materials Collection and Acclimatization}

A total number of seven hundred and fifty (750) fingerlings of $C$. gariepinus were purchased from a commercial fish farmer and transported in 50L containers filled with water to the Old Farm Research Unit of the Department of Water, Aquaculture and Fisheries Technology, Bosso Campus, Federal University of Technology, Minna, Nigeria. The fishes were placed in fish ponds with water for acclimatization. The fishes were fed to satiation twice daily 
(morning and evening) with Blue Crown feed (3mm) for 14 days ( 2 weeks) for the acclimatization. The holding water was changed every 3 days during the period.

The vitamins A, C and E granules or pellets (500g each) were purchased from commercial chemical stores. The toxicant, $\mathrm{Cd}$ (2 units of $100 \mathrm{~g}$ ) analar grades were purchased from commercial chemical stores and stored in a cool dry condition throughout the period of the experiment. This toxicant was administered according to the sub-lethal concentrations of the treatments during the chronic phase of the exposure.

\subsection{Experimental Set-up}

Five treatments including control with two replicates in each treatment were set-up for the Cd, Vitamin A, C and E; and the sub-lethal exposures were run for a period of twelve (12) weeks. The treatments are $0 \%$ (control), 15\%, 20\%, 25\% and $30 \%$ which translated into $12 \mathrm{mg} / \mathrm{L}, 16 \mathrm{mg} / \mathrm{L}, 20 \mathrm{mg} / \mathrm{L}$ and $24 \mathrm{mg} / \mathrm{L}$ of the $\mathrm{LC}_{50}$, respectively. The groups of treatments were tagged $\mathrm{Cd}\left(\mathrm{Cd}\right.$ only with $\mathrm{T}_{1}-\mathrm{T}_{4}$ and replicates), second CdVA (Cd+vitamin A with $\mathrm{T}_{1}-\mathrm{T}_{4}$ and replicates), third CdVC $\left(\mathrm{Cd}+\right.$ vitamin $\mathrm{C}$ with $\mathrm{T}_{1}-\mathrm{T}_{4}$ and replicates) and fourth $\mathrm{CdVE}$ $\left(\mathrm{Cd}+\right.$ vitamin $\mathrm{E}$ with $\mathrm{T}_{1}-\mathrm{T}_{4}$ and replicates). Each treatment was in two replicates containing 20 fish in $20 \mathrm{~L}$ plastic aquarium for the $\mathrm{Cd}$, Vitamins $\mathrm{A}, \mathrm{C}$ and $\mathrm{E}$ supplemented exposures. The water was changed and fresh toxicant and the vitamins with the same set of concentrations were added at every 72 hours according to Organization for Economic Cooperation and Development [22] standards. Three fish samples were picked at random and sacrificed from each trough on every $14^{\text {th }}$ day for the twelve weeks exposure period. The liver, gills and kidney were excised, homogenized in sodium phosphate buffer solution using ceramic mortar and pestle; and stored in sample tubes, then refrigerated until needed for analyses of AST.

\subsection{Preparation of Sodium Phosphate Buffer}

Sodium phosphate buffer solution $(0.2 \mathrm{M})$ was prepared from the mixture of sodium dihydrogen orthophosphate with $0.1 \mathrm{M}$ and disodium hydrogen orthophosphate with $0.1 \mathrm{M}$. The $\mathrm{pH}$ was adjusted to 8.0 .

\subsection{Aspartate Aminotransferase (AST) Determination}

Fish tissues' AST were determined as described by Reitman and Frankel [24] from all the treatments and replicates. Spectro-photometric method was used for the assay of AST. The homogenates were prepared in the laboratories as follow: $100 \mu \mathrm{l}(0.1 \mathrm{ml})$ of the tissue homogenate was added into test tubes with $500 \mu \mathrm{l}(0.5 \mathrm{ml})$ of reagent 1 (buffer). The mixture was incubated for 60 minutes at $37^{\circ} \mathrm{C}$. Subsequently, $500 \mu \mathrm{l}(0.5 \mathrm{ml})$ of reagent $2(2,4-$ dinitrophenylhydrazine) was added and kept for 20 minutes at $25^{\circ} \mathrm{C}$. The reaction was terminated with the addition of $5000 \mu \mathrm{l}(5.0 \mathrm{ml})$ of $0.4 \mathrm{Mol} / \mathrm{L} \mathrm{NaOH}$ to the mixture. The blank was prepared with $500 \mu \mathrm{l}(0.5 \mathrm{ml})$ of reagent $t_{1}$ and $0.1 \mu \mathrm{l}$ $(100 \mu 1)$ of distilled water. The absorbance was read at 546 $\mathrm{nm}$. These analyses were carried out in the Drug and Vaccine
Laboratory Unit of STEP B, of the Federal University of Technology, Bosso Campus, Minna, Niger State.

\subsection{Data Analyses}

The antioxidants levels in samples exposed to sub-lethal concentration of the toxicant as well as those treatments supplemented with vitamins were analysed using One Way Analysis of Variance followed by Duncan Multiple Range Test to separate the means where significant at $\mathrm{P} \leq 0.05$ level of significance using SPSS Statistical Package (version 20.0 for Windows).

\section{Results and Discussions}

\subsection{AST Production Levels in Organs of C. gariepinus Exposed to $\mathrm{CdCl}_{2}$ and the Respective Supplemented Treatments with Vitamins $A, C$ and $E$}

From the results of the samples exposed to sub-lethal concentrations of $\mathrm{CdCl}_{2}$, the AST production levels in the liver of the fish showed that $T_{1}$ and $T_{4}$ mean values in the $2^{\text {nd }}$ and $4^{\text {th }}$ weeks of exposure are significantly higher than other treatments including the control. Also, the levels of AST production in this regard are relatively high in all treatments. $\mathrm{T}_{1}$ mean values in both $6^{\text {th }}$ and $8^{\text {th }}$ weeks of exposure are significantly higher than other treatments including the control. Similarly, the $T_{3}$ mean values in the $10^{\text {th }}$ week of exposure are significantly higher than other treatments including the control. The highest mean value of AST produced in the liver was $135.00 \pm 0.18 \mathrm{nM} / \mathrm{mg}$ obtained in $\mathrm{T}_{1}$ at the end of the $8^{\text {th }}$ week of exposure. (Table 1). In another development, the $T_{3}$ mean values in both $2^{\text {nd }}$ and $4^{\text {th }}$ weeks of exposure are significantly higher than other treatments including the control. In like manner, $T_{4}, T_{1}$ and $T_{3}$ mean values in the $6^{\text {th }}, 8^{\text {th }}$ and 10 th weeks of exposure, respectively are significantly higher than other treatments including the control. The highest mean value of AST produced in the kidneys of the fish was $145.00 \pm 0.18 \mathrm{nM} / \mathrm{mg}$ obtained in $\mathrm{T}_{3}$ at the end of the $4^{\text {th }}$ week of exposure. (Table 2). Furthermore, the control mean values in the gills of the samples in $T_{1}-T_{3}$ at the end of the $2^{\text {nd }}, 4^{\text {th }}$ and $6^{\text {th }}$ week of exposure, respectively are significantly higher than other treatments. $T_{2}$ and $T_{1}$ mean values in the $8^{\text {th }}$ and $10^{\text {th }}$ weeks of exposure are significantly higher than other treatments including the control. $T_{1}$ mean value in the $10^{\text {th }}$ week of exposure recorded the highest AST production value of $137.97 \pm 0.09 \mathrm{nM} / \mathrm{mg}$. (Table 3 ).

From the results of the samples exposed to sub-lethal concentrations of $\mathrm{CdCl}_{2}$ and supplemented with vitamin $\mathrm{A}$, the AST production levels in the liver of the fish showed that $\mathrm{T}_{3}$ mean values in the $2^{\text {nd }}$ and $4^{\text {th }}$ weeks of exposure are significantly higher than other treatments. Likewise, $\mathrm{T}_{4}$ mean values in both $6^{\text {th }}$ and $8^{\text {th }}$ weeks of exposure are significantly higher than other treatments. The highest mean value of AST produced in the liver was $132.19 \pm 0.18 \mathrm{nM} / \mathrm{mg}$ obtained in $\mathrm{T}_{4}$ at the end of the $8^{\text {th }}$ week of exposure. (Table 4). In another development, the $\mathrm{T}_{2}$ and $\mathrm{T}_{3}$ mean values in the kidney of the samples in the $2^{\text {nd }}$ and $4^{\text {th }}$ weeks of exposure are significantly 
higher than other treatments. In like manner, $T_{1}$ and $T_{3}$ mean values in the $6^{\text {th }}$ and $8^{\text {th }}$ weeks of exposure, respectively are significantly higher than other treatments. The highest mean value of AST produced in the kidneys of the fish was $113.91 \pm 0.09 \mathrm{nM} / \mathrm{mg}$ obtained in $T_{1}$ at the end of the $6^{\text {th }}$ week of exposure. (Table 5). Furthermore, the control mean values in the gills of the samples in $\mathrm{T}_{4}$ and $\mathrm{T}_{2}$ at the end of the $2^{\text {nd }}$ and $4^{\text {th }}$ weeks of exposure, respectively are significantly higher than other treatments. $T_{1}$ mean values in both $6^{\text {th }}$ and $8^{\text {th }}$ weeks of exposure are significantly higher than other treatments. $\mathrm{T}_{1}$ mean value in the $6^{\text {th }}$ week of exposure recorded the highest AST production value of $120.94 \pm 0.36 \mathrm{nM} / \mathrm{mg}$. (Table 6).

Table 1 AST production levels in the Liver of C. gariepinus exposed to sub-lethal concentrations of $\mathrm{CdCl}_{2}$ for a period of 12 weeks.

\begin{tabular}{lllllll}
\hline & $\mathbf{1}^{\text {st }}$ & $\mathbf{2}^{\text {nd }}$ & $\mathbf{3}^{\text {rd }}$ & $\mathbf{4}^{\text {th }}$ & $\mathbf{5}^{\text {th }}$ & $\mathbf{6}^{\text {th }}$ \\
\hline $\mathrm{CR}$ & $90.63 \pm 0.18^{\mathrm{n}}$ & $105.00 \pm 0.18^{\mathrm{l}}$ & $35.63 \pm 0.18^{\mathrm{b}}$ & $6.56 \pm 0.36^{\mathrm{a}}$ & $91.25 \pm 0.00^{\mathrm{c}}$ & $19.22 \pm 0.27^{\mathrm{a}}$ \\
$\mathrm{T}_{1}$ & $101.72 \pm 0.27^{\mathrm{a}}$ & $63.59 \pm 0.09^{\mathrm{h}}$ & $110.16 \pm 0.09^{\mathrm{n}}$ & $135.00 \pm 0.18^{\mathrm{o}}$ & $75.63 \pm 0.18^{\mathrm{a}}$ & $101.88 \pm 0.18^{\mathrm{f}}$ \\
$\mathrm{T}_{2}$ & $44.69 \pm 0.18^{\mathrm{k}}$ & $90.94 \pm 0.18^{\mathrm{k}}$ & $12.66 \pm 0.27^{\mathrm{a}}$ & $113.59 \pm 0.27^{\mathrm{m}}$ & $0.00 \pm 0.00$ & $0.00 \pm 0.00$ \\
$\mathrm{~T}_{3}$ & $12.03 \pm 0.09^{\mathrm{c}}$ & $14.06 \pm 0.18^{\mathrm{e}}$ & $53.91 \pm 0.09^{\mathrm{d}}$ & $36.25 \pm 0.18^{\mathrm{h}}$ & $94.06 \pm 0.18^{\mathrm{d}}$ & $0.00 \pm 0.00$ \\
$\mathrm{~T}_{4}$ & $9.38 \pm 0.36^{\mathrm{b}}$ & $115.63 \pm 0.18^{\mathrm{m}}$ & $103.44 \pm 0.18^{\mathrm{k}}$ & $34.53 \pm 0.27^{\mathrm{g}}$ & $0.00 \pm 0.00$ & $0.00 \pm 0.00$ \\
\hline
\end{tabular}

Mean values and standard errors with different alphabets along the column are significantly different from each other at $\mathrm{P} \leq 0.05$. The AST mean value unit is $\mathrm{nM} / \mathrm{mg}$.

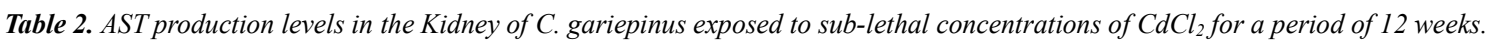

\begin{tabular}{|c|c|c|c|c|c|c|}
\hline & $1^{\text {st }}$ & $2^{\text {nd }}$ & $3^{\text {rd }}$ & $4^{\text {th }}$ & $5^{\text {th }}$ & $6^{\text {th }}$ \\
\hline $\mathrm{CR}$ & $47.03 \pm 0.09^{1}$ & $15.31 \pm 0.18^{\mathrm{f}}$ & $70.00 \pm 0.18^{\mathrm{e}}$ & $13.59 \pm 0.81^{\mathrm{d}}$ & $120.31 \pm 0.18^{\mathrm{g}}$ & $45.47 \pm 0.45^{\mathrm{c}}$ \\
\hline $\mathrm{T}_{1}$ & $23.91 \pm 0.09^{\mathrm{g}}$ & $82.19 \pm 0.18^{\mathrm{i}}$ & $103.91 \pm 0.27^{1}$ & $123.75 \pm 0.18^{n}$ & $109.69 \pm 0.18^{f}$ & $78.75 \pm 0.36^{\mathrm{e}}$ \\
\hline $\mathrm{T}_{2}$ & $35.94 \pm 0.18^{\mathrm{i}}$ & $0.47 \pm 0.09^{\mathrm{a}}$ & $79.84 \pm 0.27^{\mathrm{g}}$ & $91.88 \pm 0.18^{1}$ & $0.00 \pm 0.00$ & $0.00 \pm 0.00$ \\
\hline $\mathrm{T}_{3}$ & $62.34 \pm 0.27^{\mathrm{m}}$ & $145.00 \pm 0.18^{\mathrm{n}}$ & $50.00 \pm 0.18^{c}$ & $17.81 \pm 0.18^{\mathrm{e}}$ & $129.84 \pm 0.27^{\mathrm{h}}$ & $0.00 \pm 0.00$ \\
\hline $\mathrm{T}_{4}$ & $20.16 \pm 0.09^{f}$ & $9.53 \pm 0.09^{c}$ & $106.56 \pm 0.18^{\mathrm{m}}$ & $12.66 \pm 0.27^{\mathrm{c}}$ & $0.00 \pm 0.00$ & $0.00 \pm 0.00$ \\
\hline
\end{tabular}

Mean values and standard errors with different alphabets along the column are significantly different from each other at $\mathrm{P} \leq 0.05$. The AST mean value unit is $\mathrm{nM} / \mathrm{mg}$.

Table 3. AST production levels in the Gill of C. gariepinus exposed to sub-lethal concentrations of CdCl, for a period of 12 weeks.

\begin{tabular}{llllll}
\hline & $\mathbf{1}^{\text {st }}$ & $\mathbf{2}^{\text {nd }}$ & $\mathbf{3}^{\text {rd }}$ & $\mathbf{4}^{\text {th }}$ & $\mathbf{5}^{\text {th }}$ \\
\hline $\mathrm{CR}$ & $41.09 \pm 0.09^{\mathrm{j}}$ & $152.19 \pm 0.18^{\mathrm{o}}$ & $120.16 \pm 0.09^{\mathrm{o}}$ & $9.69 \pm 0.18^{\mathrm{b}}$ & $100.16 \pm 0.09^{\mathrm{e}}$ \\
$\mathrm{T}_{1}$ & $14.53 \pm 0.27^{\mathrm{d}}$ & $20.63 \pm 0.18^{\mathrm{g}}$ & $97.03 \pm 0.09^{\mathrm{j}}$ & $23.91 \pm 0.09^{\mathrm{f}}$ & $42.19 \pm 0.18^{\mathrm{b}}$ \\
$\mathrm{T}_{2}$ & $4.06 \pm 0.18^{\mathrm{a}}$ & $88.44 \pm 0.18^{\mathrm{j}}$ & $95.47 \pm 0.09^{\mathrm{i}}$ & $84.38 \pm 0.18^{\mathrm{k}}$ & $0.00 \pm 0.00$ \\
$\mathrm{~T}_{3}$ & $19.06 \pm 0.36^{\mathrm{e}}$ & $2.66 \pm 0.27^{\mathrm{b}}$ & $79.22 \pm 0.09^{\mathrm{f}}$ & $47.19 \pm 0.36^{\mathrm{j}}$ & $83.75 \pm 0.18^{\mathrm{b}}$ \\
$\mathrm{T}_{4}$ & $25.63 \pm 0.18^{\mathrm{h}}$ & $11.25 \pm 0.18^{\mathrm{d}}$ & $88.91 \pm 0.09^{\mathrm{h}}$ & $38.59 \pm 0.09^{\mathrm{i}}$ & $0.00 \pm 0.00$ \\
\hline
\end{tabular}

Mean values and standard errors with different alphabets along the column are significantly different from each other at $\mathrm{P} \leq 0.05$. The AST mean value unit is $\mathrm{nM} / \mathrm{mg}$.

Table 4. AST production levels in the Liver of C. gariepinus exposed to sub-lethal concentrations of CdCl ${ }_{2}$ and supplemented with vitamin A for a period of 12 weeks.

\begin{tabular}{llllll}
\hline & $\mathbf{1}^{\text {st }}$ & $\mathbf{2}^{\text {nd }}$ & $\mathbf{3}^{\text {rd }}$ & $\mathbf{4}^{\text {th }}$ & $\mathbf{5}^{\text {th }}$ \\
\hline $\mathrm{CR}$ & $90.63 \pm 0.18^{\mathrm{n}}$ & $105.00 \pm 0.18^{\mathrm{n}}$ & $35.63 \pm 0.18^{\mathrm{c}}$ & $6.56 \pm 0.36^{\mathrm{c}}$ & $91.25 \pm 0.00^{\mathrm{a}}$ \\
$\mathrm{T}_{1}$ & $66.09 \pm 0.27^{\mathrm{k}}$ & $25.78 \pm 0.45^{\mathrm{f}}$ & $97.34 \pm 0.27^{\mathrm{g}}$ & $30.94 \pm 0.18^{\mathrm{i}}$ & $19.22 \pm 0.27^{\mathrm{a}}$ \\
$\mathrm{T}_{2}$ & $46.41 \pm 0.89^{\mathrm{d}}$ & $26.41 \pm 0.27^{\mathrm{g}}$ & $92.03 \pm 0.27^{\mathrm{f}}$ & $19.06 \pm 0.18^{\mathrm{g}}$ & $0.00 \pm 0.00$ \\
$\mathrm{~T}_{3}$ & $72.97 \pm 0.27^{1}$ & $78.59 \pm 0.27^{\mathrm{k}}$ & $20.78 \pm 0.09^{\mathrm{a}}$ & $93.44 \pm 0.18^{\mathrm{n}}$ & $0.00 \pm 0.00$ \\
$\mathrm{~T}_{4}$ & $52.81 \pm 0.18^{\mathrm{g}}$ & $45.31 \pm 0.18^{\mathrm{h}}$ & $127.66 \pm 0.09^{\circ}$ & $132.19 \pm 0.18^{\mathrm{o}}$ & $0.00 \pm 0.00$ \\
\hline
\end{tabular}

Mean values and standard errors with different alphabets along the column are significantly different from each other at $\mathrm{P} \leq 0.05$. The AST mean value unit is $\mathrm{nM} / \mathrm{mg}$.

Table 5. AST production levels in the Kidney of C. gariepinus exposed to sub-lethal concentrations of CdCl $\mathrm{Cnd}_{2}$ supplemented with vitamin A for a period of 12 weeks.

\begin{tabular}{llllll}
\hline & $\mathbf{1}^{\text {st }}$ & $\mathbf{2}^{\text {nd }}$ & $\mathbf{3}^{\text {rd }}$ & $\mathbf{4}^{\text {th }}$ & $\mathbf{5}^{\text {th }}$ \\
\hline $\mathrm{CR}$ & $47.03 \pm 0.09^{\mathrm{e}}$ & $15.31 \pm 0.18^{\mathrm{d}}$ & $70.00 \pm 0.18^{\mathrm{e}}$ & $13.59 \pm 0.81^{\mathrm{e}}$ & $120.31 \pm 0.18^{\mathrm{d}}$ \\
$\mathrm{T}_{1}$ & $55.16 \pm 0.09^{\mathrm{h}}$ & $45.63 \pm 0.18^{\mathrm{i}}$ & $113.91 \pm 0.09^{\mathrm{l}}$ & $16.72 \pm 0.09^{\mathrm{f}}$ & $0.00 \pm 0.00$ \\
$\mathrm{~T}_{2}$ & $77.97 \pm 0.09^{\mathrm{m}}$ & $14.06 \pm 0.18^{\mathrm{c}}$ & $33.59 \pm 0.09^{\mathrm{b}}$ & $31.72 \pm 0.27^{\mathrm{j}}$ & $0.00 \pm 0.00$ \\
$\mathrm{~T}_{3}$ & $51.09 \pm 0.27^{\mathrm{f}}$ & $90.94 \pm 0.36^{1}$ & $101.56 \pm 0.36^{\mathrm{h}}$ & $34.69 \pm 0.18^{\mathrm{k}}$ & $0.00 \pm 0.00$ \\
$\mathrm{~T}_{4}$ & $57.50 \pm 0.18^{\mathrm{j}}$ & $71.88 \pm 0.18^{\mathrm{j}}$ & $106.88 \pm 0.36^{\mathrm{j}}$ & $4.69 \pm 0.54^{\mathrm{a}}$ & $0.00 \pm 0.00$ \\
\hline
\end{tabular}

Mean values and standard errors with different alphabets along the column are significantly different from each other at $\mathrm{P} \leq 0.05$. The AST mean value unit is $\mathrm{nM} / \mathrm{mg}$. 
Table 6. AST production levels in the Gill of C. gariepinus exposed to sub-lethal concentrations of $\mathrm{CdCl}_{2}$ and supplemented with vitamin A for a period of 12 weeks.

\begin{tabular}{llllll}
\hline & $\mathbf{1}^{\text {st }}$ & $\mathbf{2}^{\text {nd }}$ & $\mathbf{3}^{\text {rd }}$ & $\mathbf{4}^{\text {th }}$ & $\mathbf{5}^{\text {th }}$ \\
\hline $\mathrm{CR}$ & $41.09 \pm 0.09^{\mathrm{b}}$ & $152.19 \pm 0.18^{\mathrm{o}}$ & $120.16 \pm 0.09^{\mathrm{m}}$ & $9.69 \pm 0.18^{\mathrm{d}}$ & $100.16 \pm 0.09^{\mathrm{c}}$ \\
$\mathrm{T}_{1}$ & $56.88 \pm 0.18^{\mathrm{i}}$ & $17.19 \pm 0.18^{\mathrm{e}}$ & $120.94 \pm 0.36^{\mathrm{n}}$ & $89.53 \pm 0.09^{\mathrm{m}}$ & $42.19 \pm 0.18^{\mathrm{b}}$ \\
$\mathrm{T}_{2}$ & $41.41 \pm 0.27^{\mathrm{c}}$ & $103.28 \pm 0.09^{\mathrm{m}}$ & $103.59 \pm 0.27^{\mathrm{i}}$ & $44.38 \pm 0.18^{1}$ & $93.59 \pm 0.27^{\mathrm{b}}$ \\
$\mathrm{T}_{3}$ & $4.53 \pm 0.09^{\mathrm{a}}$ & $10.16 \pm 0.27^{\mathrm{b}}$ & $42.03 \pm 0.27^{\mathrm{d}}$ & $5.00 \pm 0.00^{\mathrm{b}}$ & $0.00 \pm 0.00$ \\
$\mathrm{~T}_{4}$ & $101.72 \pm 0.27^{\mathrm{b}}$ & $2.03 \pm 0.27^{\mathrm{a}}$ & $112.50 \pm 0.18^{\mathrm{k}}$ & $23.75 \pm 0.18^{\mathrm{h}}$ & $0.00 \pm 0.00$ \\
\hline
\end{tabular}

Mean values and standard errors with different alphabets along the column are significantly different from each other at $\mathrm{P} \leq 0.05$. The AST mean value unit is $\mathrm{nM} / \mathrm{mg}$.

From the results of the samples exposed to sub-lethal concentrations of $\mathrm{CdCl}_{2}$ and supplemented with vitamin $\mathrm{C}$, the AST production levels in the liver of the fish showed that $\mathrm{T}_{3}$ and $\mathrm{T}_{4}$ mean values in the $2^{\text {nd }}$ and $4^{\text {th }}$ weeks of exposure, respectively are significantly higher than other treatments. Likewise, $T_{1}$ and $T_{4}$ mean values in the $6^{\text {th }}$ and $8^{\text {th }}$ weeks of exposure are significantly higher than other treatments. Also, $\mathrm{T}_{1}$ in both $10^{\text {th }}$ and $12^{\text {th }}$ weeks of exposure are significantly higher than other treatments. The highest mean value of AST produced in the liver was $128.44 \pm 0.36 \mathrm{nM} / \mathrm{mg}$ obtained in $\mathrm{T}_{1}$ at the end of the $10^{\text {th }}$ week of exposure. (Table 7). In another development, the $\mathrm{T}_{1}$ and $\mathrm{T}_{4}$ mean values in the kidney of the samples in the $2^{\text {nd }}$ and $4^{\text {th }}$ weeks of exposure are significantly higher than other treatments. In like manner, $\mathrm{T}_{3}$ and $\mathrm{T}_{2}$ mean values in the $6^{\text {th }}$ and $8^{\text {th }}$ weeks of exposure, respectively are significantly higher than other treatments. Similarly, $\mathrm{T}_{3}$ and $\mathrm{T}_{1}$ mean values in the $10^{\text {th }}$ and $12^{\text {th }}$ weeks of exposure, respectively are significantly higher than other treatments. The highest mean value of AST produced in the kidneys of the fish was $114.84 \pm 0.09 \mathrm{nM} / \mathrm{mg}$ obtained in $\mathrm{T}_{3}$ at the end of the $10^{\text {th }}$ week of exposure. (Table 8). Furthermore, $\mathrm{T}_{1}$ and $\mathrm{T}_{3}$ mean values in the gills of the samples at the end of the $2^{\text {nd }}$ and $4^{\text {th }}$ weeks of exposure, respectively are significantly higher than other treatments. $T_{2}$ and $T_{3}$ mean values in the $6^{\text {th }}$ and $8^{\text {th }}$ weeks of exposure are significantly higher than other treatments. $\mathrm{T}_{2}$ mean values in $10^{\text {th }}$ and $12^{\text {th }}$ weeks of exposure, respectively are significantly higher than other treatments. $\mathrm{T}_{2}$ mean value in the $12^{\text {th }}$ week of exposure recorded the highest AST production value of $125.16 \pm 0.27 \mathrm{nM} / \mathrm{mg}$. (Table 9).

Table 7. AST production levels in the Liver of C. gariepinus exposed to sub-lethal concentrations of $\mathrm{CdCl}_{2}$ and supplemented with vitamin $\mathrm{C}$ for a period of 12 weeks.

\begin{tabular}{lllllll}
\hline & $\mathbf{1}^{\text {st }}$ & $\mathbf{2}^{\text {nd }}$ & $\mathbf{3}^{\text {rd }}$ & $\mathbf{4}^{\text {th }}$ & $\mathbf{5}^{\text {th }}$ & $\mathbf{6}^{\text {th }}$ \\
\hline $\mathrm{CR}$ & $90.63 \pm 0.18^{\mathrm{o}}$ & $105.00 \pm 0.18^{\mathrm{m}}$ & $35.63 \pm 0.18^{\mathrm{b}}$ & $6.56 \pm 0.36^{\mathrm{b}}$ & $91.25 \pm 0.00^{\mathrm{e}}$ & $19.22 \pm 0.27^{\mathrm{b}}$ \\
$\mathrm{T}_{1}$ & $54.53 \pm 0.27^{1}$ & $0.00 \pm 0.00$ & $123.91 \pm 0.09^{1}$ & $24.84 \pm 0.27^{\mathrm{h}}$ & $128.44 \pm 0.36^{\mathrm{k}}$ & $105.31 \pm 0.18^{\mathrm{h}}$ \\
$\mathrm{T}_{2}$ & $23.91 \pm 0.27^{\mathrm{c}}$ & $57.81 \pm 0.18^{\mathrm{i}}$ & $0.00 \pm 0.00$ & $76.56 \pm 0.18^{\mathrm{l}}$ & $113.75 \pm 0.18^{\mathrm{i}}$ & $46.56 \pm 0.18^{\mathrm{e}}$ \\
$\mathrm{T}_{3}$ & $73.44 \pm 0.36^{\mathrm{n}}$ & $81.88 \pm 0.18^{\mathrm{k}}$ & $101.72 \pm 0.27^{\mathrm{g}}$ & $12.19 \pm 0.18^{\mathrm{d}}$ & $108.13 \pm 0.18^{\mathrm{h}}$ & $0.00 \pm 0.00$ \\
$\mathrm{~T}_{4}$ & $62.66 \pm 0.09^{\mathrm{m}}$ & $93.91 \pm 0.09^{1}$ & $100.31 \pm 0.18^{\mathrm{f}}$ & $85.16 \pm 0.27^{\mathrm{m}}$ & $0.00 \pm 0.00$ & $0.00 \pm 0.00$ \\
\hline
\end{tabular}

Mean values and standard errors with different alphabets along the column are significantly different from each other at $\mathrm{P} \leq 0.05$. The AST mean value unit is $\mathrm{nM} / \mathrm{mg}$.

Table 8. AST production levels in the Kidney of C. gariepinus exposed to sub-lethal concentrations of CdCl $\mathrm{C}_{2}$ and supplemented with vitamin $C$ for a period of 12 weeks.

\begin{tabular}{lllllll}
\hline & $\mathbf{1}^{\text {st }}$ & $\mathbf{2}^{\text {nd }}$ & $\mathbf{3}^{\text {rd }}$ & $\mathbf{4}^{\text {th }}$ & $\mathbf{5}^{\text {th }}$ \\
\hline $\mathrm{CR}$ & $47.03 \pm 0.09^{\mathrm{j}}$ & $15.31 \pm 0.18^{\mathrm{b}}$ & $70.00 \pm 0.18^{\mathrm{d}}$ & $13.59 \pm 0.81^{\mathrm{e}}$ & $120.31 \pm 0.18^{\mathrm{k}}$ \\
$\mathrm{T}_{1}$ & $43.44 \pm 0.18^{\mathrm{i}}$ & $16.72 \pm 0.27^{\mathrm{c}}$ & $89.06 \pm 0.18^{\mathrm{e}}$ & $6.41 \pm 0.27^{\mathrm{a}}$ & $26.56 \pm 0.36^{\mathrm{a}}$ \\
$\mathrm{T}_{2}$ & $17.03 \pm 0.09^{\mathrm{b}}$ & $29.83 \pm 0.98^{\mathrm{g}}$ & $0.00 \pm 0.00$ & $65.78 \pm 0.09^{\mathrm{k}}$ & $106.72 \pm 0.09^{\mathrm{g}}$ \\
$\mathrm{T}_{3}$ & $12.97 \pm 0.27^{\mathrm{a}}$ & $23.75 \pm 0.18^{\mathrm{e}}$ & $108.91 \pm 0.09^{\mathrm{i}}$ & $0.00 \pm 0.00$ & $1.25 \pm 0.15^{\mathrm{d}}$ & $114.84 \pm 0.09^{\mathrm{j}}$ \\
$\mathrm{T}_{4}$ & $29.53 \pm 0.09^{\mathrm{e}}$ & $78.75 \pm 0.36^{\mathrm{j}}$ & $0.00 \pm 0.00$ & $35.94 \pm 0.18^{\mathrm{i}}$ & $0.00 \pm 0.00$ & $0.00 \pm 0.00$ \\
\hline
\end{tabular}

Mean values and standard errors with different alphabets along the column are significantly different from each other at $\mathrm{P} \leq 0.05$. The AST mean value unit is $\mathrm{nM} / \mathrm{mg}$.

Table 9. AST production levels in the Gill of C. gariepinus exposed to sub-lethal concentrations of CdCl 2 and supplemented with vitamin C for a period of 12 weeks.

\begin{tabular}{llllll}
\hline & $\mathbf{1}^{\text {st }}$ & $\mathbf{2}^{\text {nd }}$ & $\mathbf{3}^{\text {rd }}$ & $\mathbf{4}^{\text {th }}$ & $\mathbf{5}^{\text {th }}$ \\
\hline $\mathrm{CR}$ & $41.09 \pm 0.09^{\mathrm{g}}$ & $152.19 \pm 0.18^{\mathrm{n}}$ & $120.16 \pm 0.09^{\mathrm{j}}$ & $9.69 \pm 0.1 \mathrm{sa} 8^{\mathrm{c}}$ & $100.16 \pm 0.09^{\mathrm{f}}$ \\
$\mathrm{T}_{1}$ & $48.44 \pm 0.36^{\mathrm{k}}$ & $28.59 \pm 0.27^{\mathrm{f}}$ & $45.63 \pm 0.18^{\mathrm{c}}$ & $63.13 \pm 0.18^{\mathrm{j}}$ & $38.75 \pm 0.18^{\mathrm{b}}$ \\
$\mathrm{T}_{2}$ & $32.66 \pm 0.27^{\mathrm{f}}$ & $2.97 \pm 0.45^{\mathrm{a}}$ & $121.25 \pm 0.18^{\mathrm{k}}$ & $17.81 \pm 0.18^{\mathrm{g}}$ & $88.91 \pm 0.09^{\mathrm{d}}$ \\
$\mathrm{T}_{3}$ & $42.19 \pm 0.18^{\mathrm{h}}$ & $30.31 \pm 0.18^{\mathrm{h}}$ & $107.66 \pm 0.09^{\mathrm{h}}$ & $85.31 \pm 0.18^{\mathrm{n}}$ & $63.75 \pm 0.18^{\mathrm{g}}$ \\
$\mathrm{T}_{4}$ & $25.00 \pm 0.18^{\mathrm{d}}$ & $17.81 \pm 0.18^{\mathrm{d}}$ & $7.81 \pm 0.18^{\mathrm{a}}$ & $16.41 \pm 0.09^{\mathrm{f}}$ & $0.44 \pm 0.18^{\mathrm{c}}$ \\
\hline
\end{tabular}

Mean values and standard errors with different alphabets along the column are significantly different from each other at $\mathrm{P} \leq 0.05$. The AST mean value unit is $\mathrm{nM} / \mathrm{mg}$. 
From the results of the samples exposed to sub-lethal concentrations of $\mathrm{CdCl}_{2}$ and supplemented with vitamin $\mathrm{E}$, the AST production levels in the liver of the fish showed that $\mathrm{T}_{4}$ and $\mathrm{T}_{2}$ mean values in the $2^{\text {nd }}$ and $4^{\text {th }}$ weeks of exposure, respectively are significantly higher than other treatments. Likewise, $T_{1}$ and $T_{2}$ mean values in the $6^{\text {th }}$ and $8^{\text {th }}$ weeks of exposure are significantly higher than other treatments. Also, $\mathrm{T}_{2}$ in both $10^{\text {th }}$ and $12^{\text {th }}$ weeks of exposure are significantly higher than other treatments. The highest mean value of AST produced in the liver was $150.63 \pm 0.18 \mathrm{nM} / \mathrm{mg}$ obtained in $\mathrm{T}_{2}$ at the end of the $4^{\text {th }}$ week of exposure. (Table 10). Furthermore, $T_{3}$ and $T_{4}$ mean values in the kidneys of the samples at the end of the $2^{\text {nd }}$ and $6^{\text {th }}$ weeks of exposure, respectively are significantly higher than other treatments. The $4^{\text {th }}$ week of exposure has joint significance difference in
$\mathrm{T}_{1}$ and $\mathrm{T}_{4} \cdot \mathrm{T}_{1}$ mean values in the $8^{\text {th }}$ week of exposure are significantly higher than other treatments. $T_{4}$ mean value in the $6^{\text {th }}$ week of exposure recorded the highest AST production value of $125.78 \pm 0.27 \mathrm{nM} / \mathrm{mg}$. (Table 11). In addition to the forgoing, the $T_{3}$ and $T_{1}$ mean values in the gills of the samples in the $2^{\text {nd }}$ and $4^{\text {th }}$ weeks of exposure are significantly higher than other treatments. In like manner, $\mathrm{T}_{2}$ and $T_{3}$ mean values in the $6^{\text {th }}$ and $8^{\text {th }}$ weeks of exposure, respectively are significantly higher than other treatments. Similarly, $T_{1}$ mean values in both $10^{\text {th }}$ and $12^{\text {th }}$ weeks of exposure, respectively are significantly higher than other treatments. The highest mean value of AST produced in the gills of the fish was $133.28 \pm 0.09 \mathrm{nM} / \mathrm{mg}$ obtained in $\mathrm{T}_{1}$ at the end of the $4^{\text {th }}$ week of exposure. (Table 12).

Table 10. AST production levels in the Liver of C. gariepinus exposed to sub-lethal concentrations of CdCl $\mathrm{C}_{2}$ and supplemented with vitamin E for a period of 12 weeks.

\begin{tabular}{lllllll}
\hline & $\mathbf{1}^{\text {st }}$ & $\mathbf{2}^{\text {nd }}$ & $\mathbf{3}^{\text {rd }}$ & $\mathbf{4}^{\text {th }}$ & $\mathbf{5}^{\text {th }}$ \\
\hline $\mathrm{CR}$ & $90.63 \pm 0.18^{\mathrm{m}}$ & $105.00 \pm 0.18^{\mathrm{j}}$ & $35.63 \pm 0.18^{\mathrm{c}}$ & $6.56 \pm 0.36^{\mathrm{a}}$ & $91.25 \pm 0.00^{\mathrm{c}}$ \\
$\mathrm{T}_{1}$ & $32.03 \pm 0.27^{\mathrm{c}}$ & $27.66 \pm 0.09^{\mathrm{h}}$ & $122.50 \pm 0.18^{\mathrm{n}}$ & $32.19 \pm 0.18^{\mathrm{f}}$ & $19.22 \pm 0.27^{\mathrm{b}}$ & $30.00 \pm 0.18^{\mathrm{a}}$ \\
$\mathrm{T}_{2}$ & $73.28 \pm 0.89^{\mathrm{j}}$ & $150.63 \pm 0.18^{\mathrm{m}}$ & $106.25 \pm 0.18^{\mathrm{l}}$ & $101.88 \pm 0.36^{\mathrm{k}}$ & $75.78 \pm 0.09^{\mathrm{b}}$ \\
$\mathrm{T}_{3}$ & $32.03 \pm 0.27^{\mathrm{c}}$ & $13.28 \pm 0.45^{\mathrm{b}}$ & $84.22 \pm 0.09^{\mathrm{j}}$ & $78.59 \pm 0.27^{\mathrm{h}}$ & $117.97 \pm 0.09^{\mathrm{h}}$ & $0.00 \pm 0.00$ \\
$\mathrm{~T}_{4}$ & $75.78 \pm 0.27^{\mathrm{k}}$ & $35.00 \pm 0.18^{\mathrm{i}}$ & $40.78 \pm 0.27^{\mathrm{e}}$ & $42.50 \pm 0.18^{\mathrm{g}}$ & $0.00 \pm 0.00$ & $0.00 \pm 0.00$ \\
\hline
\end{tabular}

Mean values and standard errors with different alphabets along the column are significantly different from each other at $\mathrm{P} \leq 0.05$. The AST mean value unit is $\mathrm{nM} / \mathrm{mg}$.

Table 11. AST production levels in the Kidney of C. gariepinus exposed to sub-lethal concentrations of CdCl ${ }_{2}$ and supplemented with vitamin E for a period of 12 weeks.

\begin{tabular}{llllll}
\hline & $\mathbf{1}^{\text {st }}$ & $\mathbf{2}^{\text {nd }}$ & $\mathbf{3}^{\text {rd }}$ & $\mathbf{4}^{\text {th }}$ & $\mathbf{5}^{\text {th }}$ \\
\hline $\mathrm{CR}$ & $47.03 \pm 0.09^{\mathrm{f}}$ & $15.31 \pm 0.18^{\mathrm{e}}$ & $70.00 \pm 0.18^{\mathrm{i}}$ & $13.59 \pm 0.81^{\mathrm{c}}$ & $120.31 \pm 0.18^{\mathrm{f}}$ \\
$\mathrm{T}_{1}$ & $57.19 \pm 0.18^{\mathrm{g}}$ & $110.63 \pm 0.36^{\mathrm{k}}$ & $15.63 \pm 0.18^{\mathrm{b}}$ & $117.03 \pm 0.09^{\mathrm{n}}$ & $45.47 \pm 0.45^{\mathrm{f}}$ \\
$\mathrm{T}_{2}$ & $41.09 \pm 0.27^{\mathrm{e}}$ & $17.66 \pm 0.09^{\mathrm{g}}$ & $45.31 \pm 0.18^{\mathrm{f}}$ & $102.03 \pm 0.09^{1}$ & $0.00 \pm 0.00$ \\
$\mathrm{~T}_{3}$ & $88.28 \pm 0.27^{1}$ & $13.75 \pm 0.18^{\mathrm{c}}$ & $56.72 \pm 0.27^{\mathrm{h}}$ & $109.84 \pm 0.09^{\mathrm{m}}$ & $0.00 \pm 0.00$ \\
$\mathrm{~T}_{4}$ & $40.31 \pm 0.18^{\mathrm{d}}$ & $110.63 \pm 0.18^{\mathrm{k}}$ & $125.78 \pm 0.27^{\mathrm{o}}$ & $91.09 \pm 0.27^{\mathrm{j}}$ & $0.00 \pm 0.00$ \\
\hline
\end{tabular}

Mean values and standard errors with different alphabets along the column are significantly different from each other at $\mathrm{P} \leq 0.05$. The AST mean value unit is $\mathrm{nM} / \mathrm{mg}$.

Table 12. AST production levels in the Gill of C. gariepinus exposed to sub-lethal concentrations of CdCl ${ }_{2}$ and supplemented with vitamin E for a period of 12 weeks.

\begin{tabular}{llllll}
\hline & $\mathbf{1}^{\text {st }}$ & $\mathbf{2}^{\text {nd }}$ & $\mathbf{3}^{\text {rd }}$ & $\mathbf{4}^{\text {th }}$ & $\mathbf{5}^{\text {th }}$ \\
\hline $\mathrm{CR}$ & $41.09 \pm 0.09^{\mathrm{e}}$ & $152.19 \pm 0.18^{\mathrm{n}}$ & $120.16 \pm 0.09^{\mathrm{m}}$ & $9.69 \pm 0.18^{\mathrm{b}}$ & $100.16 \pm 0.09^{\mathrm{e}}$ \\
$\mathrm{T}_{1}$ & $26.88 \pm 0.54^{\mathrm{b}}$ & $133.28 \pm 0.09^{1}$ & $39.38 \pm 0.18^{\mathrm{d}}$ & $21.72 \pm 0.27^{\mathrm{d}}$ & $42.19 \pm 0.18^{\mathrm{d}}$ \\
$\mathrm{T}_{2}$ & $61.56 \pm 0.18^{\mathrm{h}}$ & $7.19 \pm 0.18^{\mathrm{a}}$ & $91.09 \pm 0.09^{\mathrm{k}}$ & $27.50 \pm 0.18^{\mathrm{e}}$ & $91.88 \pm 0.18^{\mathrm{d}}$ \\
$\mathrm{T}_{3}$ & $65.00 \pm 0.18^{\mathrm{i}}$ & $14.53 \pm 0.09^{\mathrm{d}}$ & $56.41 \pm 0.27^{\mathrm{g}}$ & $85.47 \pm 0.09^{\mathrm{i}}$ & $0.00 \pm 0.00$ \\
$\mathrm{~T}_{4}$ & $19.53 \pm 0.09^{\mathrm{a}}$ & $15.47 \pm 0.27^{\mathrm{f}}$ & $8.75 \pm 0.18^{\mathrm{a}}$ & $21.72 \pm 0.27^{\mathrm{d}}$ & $0.00 \pm 0.00$ \\
\hline
\end{tabular}

Mean values and standard errors with different alphabets along the column are significantly different from each other at $\mathrm{P} \leq 0.05$. The AST mean value unit is $\mathrm{nM} / \mathrm{mg}$.

\subsection{Discussions}

\subsubsection{AST Production Levels in C. gariepinus Exposed to Sub-lethal Concentrations of Cd Only}

From the results of the samples exposed to sub-lethal concentrations of $\mathrm{CdCl}_{2}$, the AST production levels in the liver of the fish showed that $T_{1}$ and $T_{4}$ mean values in the $2^{\text {nd }}$ and $4^{\text {th }}$ weeks of exposure are significantly higher than other treatments including the control. The elicitation started early in the lowest concentration and then in the highest concentration subsequently. Also, the levels of AST production in this regard are relatively high in all treatments probably due to the prevailing environmental conditions that necessitate up-regulation of the immune system. In a related development, El-Said El-Boshy et al. [12] reported that blood level activities of ALT and AST was significantly increased when the fish were exposed to 2,5 and $10 \mathrm{mg} / \mathrm{L}$ treatments for a period of 3 weeks. $T_{1}$ mean values in both $6^{\text {th }}$ and $8^{\text {th }}$ weeks of exposure are significantly higher than other treatments including the control probably due to high production and less utilization of the enzyme. This is also 
probably why the highest mean value of AST produced in the liver was $135.00 \pm 0.18 \mathrm{nM} / \mathrm{mg}$ obtained in $\mathrm{T}_{1}$ as well as at the end of the $8^{\text {th }}$ week of exposure. Similarly, the $T_{3}$ mean values in the $10^{\text {th }}$ week of exposure are significantly higher than other treatments including the control probably due to up-regulation of the defence system as the duration and concentration of the exposure increased. The presence of pollutant in the environment of aquatic organism can trigger the utilization or increased production of AST. For instance, cadmium in plasma of goldfish significantly increased the activities of plasma glutamic acid oxaloacetic acidtransaminase (GOT) and glutamic acid-pyruvic acid transaminase (GPT) [32]. In another development, the $T_{3}$ mean values in the kidney of the sample in both $2^{\text {nd }}$ and $4^{\text {th }}$ weeks of exposure are significantly higher than other treatments including the control probably due to the need to counter the onslaught of the toxicant especially at the early stage of the exposure after initial elicitation and subsequently, sustenance of the tempo as the duration of exposure increased since, the highest mean value of AST produced in the kidneys of the fish was $145.00 \pm 0.18 \mathrm{nM} / \mathrm{mg}$ obtained in $\mathrm{T}_{3}$ as well at the end of the $4^{\text {th }}$ week of exposure, and that the same $T_{3}$ mean values are significantly higher than other treatments in the $10^{\text {th }}$ week of exposure. This is also probably why $T_{4}$ and $T_{1}$ mean values in the $6^{\text {th }}$ and $8^{\text {th }}$ weeks of exposure, respectively are significantly higher than other treatments including the control due to the need for upregulation and sustenance. In like manner, increased activities of AST, ALT and ALP in Indian major carps exposed to nitrite toxicity have been reported [10]. Furthermore, the control mean values in the gills of the samples in $\mathrm{T}_{1}-\mathrm{T}_{3}$ at the end of the $2^{\text {nd }}, 4^{\text {th }}$ and $6^{\text {th }}$ week of exposure, respectively are significantly higher than other treatments. This is probably because the gills may not be very sensitive in detecting the production of the enzyme and perhaps the available concentrations have been engaged in dealing with the effects of the toxicant. Probably as the duration of exposure increased there were improved production levels and less utilization of the available enzyme. This is probably why $T_{2}$ and $T_{1}$ mean values in the $8^{\text {th }}$ and $10^{\text {th }}$ weeks of exposure are significantly higher than other treatments including the control; and the highest AST production mean value $(137.97 \pm 0.09 \mathrm{nM} / \mathrm{mg})$ was also obtained in $\mathrm{T}_{1}$ in the $10^{\text {th }}$ week of exposure.

\subsubsection{AST Production Levels in C. gariepinus Exposed to Sub-lethal Concentrations of Cd Supplemented with Vitamin $A$}

From the results of the samples exposed to sub-lethal concentrations of $\mathrm{CdCl}_{2}$ and supplemented with vitamin $\mathrm{A}$, the AST production levels in the liver of the fish showed that $\mathrm{T}_{3}$ mean values in the $2^{\text {nd }}$ and $4^{\text {th }}$ weeks of exposure are significantly higher than other treatments. The increased production levels of AST in the higher concentrations in both early and later stages of the exposure were probably necessitated by the need for drastic action against the onslaughts of the toxicant as the duration increases. Ensibi et al. [14] have indicated that the activities of antioxidant enzymes may be elevated or inhibited by biochemical stress depending on the intensity and the duration of the stress applied as well as on the susceptibility of the exposed species. The production levels were not significant in lower levels in the liver probably because of the shield provided by the vitamin. In the same vein, $\mathrm{T}_{4}$ mean values in both $6^{\text {th }}$ and $8^{\text {th }}$ weeks of exposure are significantly higher than other treatments; and the highest mean value of AST produced in the liver $(132.19 \pm 0.18 \mathrm{nM} / \mathrm{mg})$ was also obtained in $\mathrm{T}_{4}$ at the end of the $8^{\text {th }}$ week of exposure probably due to the need for up-regulation of the defence system. In another development, the $T_{2}$ and $T_{3}$ mean values in the kidney of the samples in the $2^{\text {nd }}$ and $4^{\text {th }}$ weeks of exposure are significantly higher than other treatments. The elicitation of the production of the AST in the kidney commenced in $\mathrm{T}_{2}$ and subsequently in $\mathrm{T}_{3}$ as the duration of the exposure increased probably due to the initial needs for up-regulation of the immune system to ensure survival. In like manner, $T_{1}$ mean values in the $6^{\text {th }}$ week of exposure are significantly higher than other treatments with $113.91 \pm 0.09 \mathrm{nM} / \mathrm{mg}$ as the highest AST produced in the kidneys of the fish also in $T_{1}$ at the same period of exposure probably due to less utilization in the presence of the vitamin. Furthermore, the control mean values in the gills of the samples in $T_{4}$ and $T_{2}$ at the end of the $2^{\text {nd }}$ and $4^{\text {th }}$ weeks of exposure, respectively are significantly higher than other treatments probably due to the initial need for the upregulation of the body's defence system and the early elicitation subsequently. Also in the gills as the duration of exposure increased the production levels probably become more with less utilization in lower concentrations, and also probably due to the succoring presence of the vitamin. This may be the reason why $T_{1}$ mean values in both $6^{\text {th }}$ and $8^{\text {th }}$ weeks of exposure are significantly higher than other treatments with the highest value of $120.94 \pm 0.36 \mathrm{nM} / \mathrm{mg}$ at the $6^{\text {th }}$ week of exposure.

\subsubsection{AST Production Levels in C. gariepinus Exposed to Sub-lethal Concentrations of Cd Supplemented with Vitamin C}

From the results of the samples exposed to sub-lethal concentrations of $\mathrm{CdCl}_{2}$ and supplemented with vitamin $\mathrm{C}$, the AST production levels in the liver of the fish showed that $\mathrm{T}_{3}$ and $\mathrm{T}_{4}$ mean values in the $2^{\text {nd }}$ and $4^{\text {th }}$ weeks of exposure, respectively are significantly higher than other treatments. The need for defence of the body's system against the effects of the toxicant probably prompted the increased production of the enzyme in the higher concentrations. This is also probably why the $T_{4}$ mean values are significant in the $8^{\text {th }}$ week of exposure. $T_{1}$ mean values in the $6^{\text {th }}, 10^{\text {th }}$ and $12^{\text {th }}$ weeks of exposure, respectively are significantly higher than other treatments; and is also the highest mean value of AST produced in the liver $(128.44 \pm 0.36 \mathrm{nM} / \mathrm{mg})$ at the end of the $10^{\text {th }}$ week of exposure. This is probably due to the need for high production of the enzyme at later stages of the exposure but in the presence of the vitamin there may have been less utilization in combating the effects of the toxicant. Similar 
report was given by Shalaby [26] who stated that total protein content and AST became normalized_similar to those of the control upon administration of Vitamin C. In another development, the $T_{1}$ and $T_{4}$ mean values in the kidney of the samples in the $2^{\text {nd }}$ and $4^{\text {th }}$ weeks of exposure are significantly higher than other treatments. This is likely an up-regulation of the defence system from the lowest concentration and subsequently, in the highest concentration as the duration increases. This is also probably why $\mathrm{T}_{3}, \mathrm{~T}_{2}$ and $\mathrm{T}_{1}$ mean values in the $6^{\text {th }}, 8^{\text {th }}$ and $12^{\text {th }}$ weeks of exposure, respectively are significantly higher than other treatments. Similarly, $\mathrm{T}_{3}$ mean values in the $10^{\text {th }}$ weeks of exposure, respectively are significantly higher than other treatments; and the highest mean value of AST produced in the kidneys of the fish $(114.84 \pm 0.09 \mathrm{nM} / \mathrm{mg})$ was also obtained in $\mathrm{T}_{3}$ at the end of the $10^{\text {th }}$ week of exposure probably due to the need for upregulation of the body's immune system to counteract the effects of the toxicant. Findings by Ali et al. [5] on amelioration of vitamin $\mathrm{C}$ indicated that the levels of creatinie $(28.3 \pm 1.1 \mu \mathrm{mol} / \mathrm{L})$, Cystatin C $(1932.5 \pm 38.5 \mathrm{ng} / \mathrm{ml})$, Uric acid $(4.8 \pm 0.1 \mathrm{mg} / \mathrm{day})$ and ALP $(51.6 \pm 1.1 \mathrm{IU} / \mathrm{L})$ were significantly $(\mathrm{P}<0.05)$ increased due to administration of mercuric chloride but in the presence of vitamin $\mathrm{C}$, the effects of mercuric choride on creatinine $921.9 \pm 1.4 \mu \mathrm{mol} / \mathrm{L})$, Cystatin C (1676.2 $\pm 42.2 \mathrm{ng} / \mathrm{ml})$, Uric acid $(3.9 \pm 0.1 \mathrm{mg} /$ day) and ALP $(43.3 \pm 0.8 \mathrm{IU} / \mathrm{L})$ were less compared to metalexposed specimens. They also reported that similar results were also obtained in rabbits treated with cadmium chloride and vitamin $\mathrm{C}$, and also with co-administration of both metals and vitamin C. Also, Bakare et al. [9] posited that concomitant increase in the activities of ALT and AST in the serum of treated mice indicates acute hepato-cellular injury. Furthermore, $T_{1}$ and $T_{3}$ mean values in the gills of the samples at the end of the $2^{\text {nd }}$ and $4^{\text {th }}$ weeks of exposure, respectively are significantly higher than other treatments probably for the purpose of defence against early and subsequent onslaughts of the effects of the toxicant especially as the duration increases. This is also probably why the $T_{2}$ and $T_{3}$ mean values in the $6^{\text {th }}$ and $8^{\text {th }}$ weeks of exposure are significantly higher than other treatments. $T_{2}$ mean values in $10^{\text {th }}$ and $12^{\text {th }}$ weeks of exposure, respectively are significantly higher than other treatments; and $T_{2}$ mean value in the $12^{\text {th }}$ week of exposure also recorded the highest AST production value of $125.16 \pm 0.27 \mathrm{nM} / \mathrm{mg}$ probably because after elicitation for the up-regulation of the body's immune systems there may be less utilization in combating the effects of the toxicant. In like manner, activities of the hepatic enzymes lactate dehydrogenase (LDH), alanine aminotransferase (ALAT) and aspartate aminotransferase (ASAT) were found to be significantly elevated, particularly in summer [30].

\subsubsection{AST Production Levels in C. gariepinus Exposed to Sub-lethal Concentrations of Cd Toxicant and Supplemented with Vitamin $E$}

From the results of the samples exposed to sub-lethal concentrations of $\mathrm{CdCl}_{2}$ and supplemented with vitamin $\mathrm{E}$, the AST production levels in the liver of the fish showed that $\mathrm{T}_{4}$ and $\mathrm{T}_{2}$ mean values in the $2^{\text {nd }}$ and $4^{\text {th }}$ weeks of exposure, respectively are significantly higher than other treatments. Again, there were elicitations and increased production of the enzyme in the highest concentration at early stage of the exposure probably to combat the onslaught of the toxicant; and subsequently in the lower concentrations as the duration of exposure increases probably due to the succoring presence of the vitamin. This is also probably why $T_{1}$ and $T_{2}$ mean values in the $6^{\text {th }}$ and $8^{\text {th }}$ weeks of exposure are significantly higher than other treatments. Perhaps this also applies to $T_{2}$ which in both $10^{\text {th }}$ and $12^{\text {th }}$ weeks of exposure are significantly higher than other treatments; and the highest mean value of AST produced in the liver $(150.63 \pm 0.18 \mathrm{nM} / \mathrm{mg})$ was also obtained in $T_{2}$ at the end of the $4^{\text {th }}$ week of exposure probably because the enzymes produced in the higher concentrations have been put to greater use than in lower concentrations. This is in conformity with the findings of Feng et al. [16] who reported that, the ameliorative role of vitamins was evident when Vitamin E and metallothionein treatments protected against Cd-induced damage of liver in grass carp by decreasing AST and ALT content, repairing organelles, and maintained the antioxidant system by elevating CAT, SOD, and GSH-Px activity and regulating related mRNA transcript expression. Furthermore, $\mathrm{T}_{3}$ and $\mathrm{T}_{4}$ mean values in the kidneys of the samples at the end of the $2^{\text {nd }}$ and $6^{\text {th }}$ weeks of exposure, respectively are significantly higher than other treatments due to the probable need for up-regulations of the body's defence system in tackling the effects of the toxicant especially at the inception. Similar finding was reported by Kaoud et al. [17] when they stated that exposure of Nile Tilapia to Cd resulted in significant increase in plasma AST and ALT, and also caused structural damages. The $4^{\text {th }}$ week of exposure has joint significance difference in $T_{1}$ and $T_{4}$ probably because there were needs for up- regulation in all the treatments especially at the early stage of the exposure. This may also be why $T_{4}$ mean value in the $6^{\text {th }}$ week of exposure recorded the highest AST production value of $125.78 \pm 0.27 \mathrm{nM} / \mathrm{mg}$. $\mathrm{T}_{1}$ mean values in the $8^{\text {th }}$ week of exposure are significantly higher than other treatments probably due to the presence of the vitamin and attendant less utilization of the enzyme in this lowest concentration. In addition to the forgoing, the $T_{3}$ and $T_{1}$ mean values in the gills of the samples in the $2^{\text {nd }}$ and $4^{\text {th }}$ weeks of exposure are significantly higher than other treatments probably due to the need for early protection against the toxicant in $T_{3}$ and subsequently in $T_{1}$ as the duration increased. Similarly, $T_{1}$ mean values in both $10^{\text {th }}$ and $12^{\text {th }}$ weeks of exposure, respectively are significantly higher than other treatments; and the highest mean value of AST produced in the gills of the fish $(133.28 \pm 0.09 \mathrm{nM} / \mathrm{mg})$ was also obtained in $T_{1}$ at the end of the $4^{\text {th }}$ week of exposure probably the vitamin was sufficient in providing the immune boost and hence, less utilization of the enzyme. This is also likely why $T_{2}$ and $T_{3}$ mean values in the $6^{\text {th }}$ and $8^{\text {th }}$ weeks of exposure, respectively are significantly higher than other treatments. 


\section{Conclusions and Recommendations}

There were general high production levels of AST in all treatments. The highest mean production values were recorded in the liver of CdVA, CdVC and CdVE groups mostly in samples exposed to lower concentrations. The kidneys in the $\mathrm{Cd}$ only group however, produced the highest AST value. The high production values of AST in all treatments suggest that the enzyme is a good biomarker of oxidative stress elicited by the presence of the toxicant. This also buttresses the importance of these organs in the detoxifications of the effects of xenobiotics in their immediate environment.

The highest AST mean value produced in the $\mathrm{Cd}$ only group is $145.00 \pm 0.18 \mathrm{nM} / \mathrm{mg}$, CdVA is $132.19 \pm 0.18 \mathrm{nM} / \mathrm{mg}$, $\mathrm{CdVC}$ is $128 \pm 0.36 \mathrm{nM} / \mathrm{mg}$ and CdVE is $150.63 \pm 0.18 \mathrm{nM} / \mathrm{mg}$ to attenuate the effects of the toxicant at one point and organ or the other.

\section{References}

[1] Abdel-Warith, A. A., Younis, E. M., Al-Asgah, N. A., \& Wahbi, O. M. (2011). Effect of zinc toxicity on liver histology of Nile tilapia, Oreochromis niloticus. Scientific Research Essential, 6 (17), 3760-3769.

[2] Adewolu, M. A., Adeniji, C. A., \& Adejobi, A. B. (2008). Feed utilization, growth and survival of Clarias gariepinus (Burchell, 1822) fingerlings cultured under different photoperiods. Aquaculture, 283, 64-67.

[3] Ahmad, I., Maria, V. L., Oliveira, M., Serafim, A. Bebianno, M. J., Pacheco, M., \& Santos, M. A. (2008). DNA damage and lipid peroxidation vs. protection responses in the gill of Dicentrarchus labrax L. from a contaminated coastal lagoon (Ria de Aveiro, Portugal). Science of the Total Environment, 406, 298-307.

[4] Ahmed, N. F., Sadek, K. M., Soliman, M. K., Khalil, R. H., Khafaga, A. F., Ajarem, J. S., Maodaa, S. N., Allam, A. A. (2020). Moringa Oleifera Leaf Extract Repairs the Oxidative Misbalance following Sub-Chronic Exposure to Sodium Fluoride in Nile Tilapia Oreochromis niloticus. Animals, 10, 626.

[5] Ali, S., Hussain, S., \& Ulhaq, M. (2019). Renal toxicity of heavy metals (Cadmium and Mercury) and their amelioration with ascorbic acid in rabbits. Environmental Science and Pollution Research, 26, 3909-3920.

[6] Arenas, J. J., Villafranca, M., Nieto-Guindo, E., 'Alvaro S. M., Moreno, S. M., Garrido, S., \& Abil'es, J. (2017). Effects of cyclic parenteral nutrition on parenteral-associated liver dysfunction parameters. Nutrition Journal, 16, 1-8.

[7] Athar, T., Waris, A. A. \& Nisar, M. (2018). A review on toxicity and environmental implications of heavy metals. Emergent Life Sciences Research, 4 (2), 31-37. Doi: https://doi.org/10.31783/elsr.2018.

[8] Ayyat, M. S., Ayyat, A. M., Naiel, M. A., Al-Sagheer, A. A. (2020). Reversal effects of some safe dietary supplements on lead contaminated diet induced impaired growth and associated parameters in Nile tilapia. Aquaculture, 515, 734580 .
[9] Bakare, A. A., Patel, S., Pandey, A. K., Bajpayee, M., \& Dhawan, A. (2013). DNA and oxidative damage induced in somatic organs and tissues of mouse by municipal sludge leachate. Toxicology and Industrial Health, 28, 614-623.

[10] Das, P. C., Ayyappan, S., Das, B. K., \& Jena, J. K. (2004). Nitrite toxicity in Indian major carps: sublethal effect on selected enzymes in fingerlings of Catla catla, Labeo rohita, and Cirrhinus mrigala. Comparative Biochemistry and Physiology, 138, 3 - 10.

[11] Ellakany, H., \& Gaafar, H. (2002). Effects of combined aflatoxicosis and ochratoxicosis on immunological, biochemical and histopathological measurements in broilers. $6^{\text {th }}$ Vet. Zag. Conference (7-9 Sept. 2002), Hurghada.

[12] El-Said El-Boshy, M., Gadalla, H. A., \& AbdEl-Hamied, F. M. (2014). Immunological, haematological and biochemical changes induced by short term exposure to cadmium in catfish (Clarias gariepinus). Journal of Coastal Life medicine, 2 (3), 175-180. Doi: 10.12980/JCLM.2.2014J57.

[13] El-Shenawy, N. S., \& Al-Ghamdi, O. A. (2014). Phenthoate induced oxidative stress in fresh isolated mice hepatocytes. Alleviation by ascorbic acid. Toxicology, Environment and Health Science, 6 (2), 67-80.

[14] Ensibi, C., Perez-Lopez, M., Soler-Rodriguez, F., MiguezSantiyan, M. P., Daly-Yahia, M. N., \& Hernandez-Moreno, D. (2013). Effects of deltamethrin on biometric parameters and liver biomarkers in common carp (Cyprinus carpio L.). Environmental Toxicology and Pharmacology, 36, 384-391.

[15] FAO (2003). Food Security: concepts and measurement. Rome: Food and Agriculture Organization of the United Nations. In FAO (Ed.), Trade Reforms and Food Security. pp. 25-34.

[16] Feng, Y., Huang, X., Duan, Y., Fan, W., Duan, J., Wang, K., ....., \& Yang, S. (2018). The Effects of Vitamin E and Metallothionein on the AntioxidantCapacities of CadmiumDamaged Liver in Grass Carp, Ctenopharyngodon idellus. BioMed Research International, 1-8. https://doi.org/10.1155/2018/7935396.

[17] Kaoud, H., Zaki, M., El-Dahshan, A. R., Abdelgayed, S. S. (2011). Ameliorating the toxic effects of cadmium-exposure in Nile Tiapia (Oreochromis niloticus) by using Lemna gibba L. Life Sciences, 8 (1), 185-195.

[18] Karami, A., Christianus, A., Ishak, Z., Courtenay, S. C., Sayed, M. A., Noor, A. M., \& Noor, S. H. (2010). Effect of triploidization on juvenile African catfish (Clarias gariepinus). Aquaculture International, 18, 851-858.

[19] Mehana, E. E., Khafaga, A. F., Elblehi, S. S., AbdEl-Hack, M. E., Naiel, M. A. E., Bin-Jumah, M., SarahI. Othman, S. I., \& Allam, A. A. (2020). Biomonitoring of Heavy Metal Pollution Using Acanthocephalans Parasite in Ecosystem: An Updated Overview. Animals, 10, 811, 1-15. doi: 10.3390/ani10050811.

[20] Merciai, R., Guasch, H., Kumar, A., \& Sabater, S. (2014). Trace metal concentration and fish size: variation among fish species in a Mediterranean river. Ecotoxicology and Environmental Safety, 107, 154-163.

[21] Monteiro, D. A., Rantin, F. T., \& Kalinin, A. L. (2010). Inorganic mercury exposure: toxicological effects, oxidative stress biomarkers and bioaccumulation in the tropical freshwater fish matrinx, Brycon amazonicus (Spix and Agassiz, 1829). Ecotoxicology, 19, 105-123. 
[22] Organization for Economic Cooperation and Development (2007). Maximum Acceptable Contaminants: guidance safety level. Fresh water fish (RPWS 1991). Pp. 12-28.

[23] Pratt, T. C., Cullen, F. T., Sellers, C. S., Thomas, W. L., Madensen, T. D., Daigle, L. E., Fearn, N. E., \& Gau, J. (2010). The empirical status of social learning theory: a meta-analysis. Justice Quarterly, 27: 6, 765-802. Doi: $10.1080 / 07418820903379610$.

[24] Reitman, S., \& Frankel, S. (1957). Glutamic-Pyruvate transaminase assay by colorimetric method. American Journal of Clinical Pathology, 28- 56.

[25] Saglam, D., Atli, G., Dogan, Z., Baysoy, E., Gurler, C., Eroglu, A., \& Canli, M. (2014). Response of the antioxidant system of freshwater fish (Oreochromis niloticus) exposed to metals $(\mathrm{Cd}, \mathrm{Cu})$ in different hardness. Turkish Journal of Aquatic Science, 14, 43-52.

[26] Shalaby, A. M. E. (2009). The opposing effects of ascorbic acid (Vit C) on ochratoxin toxicity in Nile Tilapia (Oreochromis niloticus). $6^{\text {th }}$ International Symposium on Tilapia in Aquaculture, Phillipines, p150-157.

[27] Shilpi, G., Shilpi, S., \& Sunita, S. (2015). Tolerance Against Heavy Metal Toxicity In Cyanobacteria: Role Of Antioxidant Defense System. International Journal of Pharmacy and Pharmaceutical Sciences, (7) (2), 0975-1491.
[28] Thakur, V., \& Kanshere, R. R. (2014). Comparative Study on the Protective Role of Vitamin C and Vitamin E on Mercury Induced Toxicity in Heteropneusts fossilis. International Research Journal of Science \& Engineering, 2 (2), 37-43.

[29] Van Der Oost, R., Beyer, J., \& Vermeulen, N. P. E. (2003) Fish bioaccumulation and biomarkers in environmental risk assessment: A review. Environmental Toxicology and Pharmacology, 13, 57-149.

[30] Yancheva, V., Stoyanova, S., Velcheva, I., Petrova, S., \& Georgieva, E. (2014). Metal bioaccumulation in common carp and rudd from the Topolnitsa reservoir, Bulgaria. Archives of industrial hygiene and toxicology, 65 (1), 1-10. DOI: 10.2478/10004-1254-65-2014-2451.

[31] Yolanda, M., \& Maria, L. I. (2012). Use of antioxidants for the treatment of cognitive and behavioural disorders in individuals with fragile X syndrome. WO2012080554.

[32] Zikic, R. V., Stajn, S., Pavlovic, Z., Ognjanovic, B. I., \& Saicic, Z. S. (2001). Activities of superoxide dismutase and catalase in erythrocyte and plasma transaminases of goldfish (Carassius auratus gibelio Bloch.) exposed to cadmium. Physiological Research, 50, 105-111. 